\title{
Occupational Stress in Working Women: Its Relationship with their Level of Emotional Intelligence and the Coping Strategies Used to Deal with Stress
}

\author{
Payal Maheshwari \\ India
}

\begin{abstract}
The present study aimed at finding out the level of Occupational stress in working women and its relationship with their level of Emotional Intelligence. It also aimed at finding out the coping strategies used by these women to deal with stress. The sample comprised of 50 women who were married and were working in the corporate private firms, having an $8 \mathrm{hr}$ (9am to 5pm) job. Judgmental/ purposive or non-probability sampling was used to select the sample. Self constructed Emotional Intelligence Scale for women, and a selfconstructed Occupational Stress Index, were used to collect the data. The coping strategies were studied through an interview. The findings revealed that most of the women had average level of occupational stress and the major stressors as perceived by them were time-management, workfamily conflict and problems with senior colleagues. Majority of the working women (46) perceived themselves as having above average level of EI. The mean scores of all the four domains of EI also fell in the high category. Significantly high negative correlations were found between the level of Occupational stress and Emotional intelligence and its domains. Positive coping methods were used to deal with occupational stress. The findings of the study are discussed in relation to its implication for the organizations.
\end{abstract}

\section{Introduction}

Occupational stress can be defined as an incompatibility between the individual and his/her work environment. Increasing occupational stress among employees is a growing problem worldwide. Work related stress of the employees consequently affects the efficiency of the organizations because when one is under stress, his ability to carry out job responsibilities gets affected.

The negative consequences of job stress on employees' health and wellbeing are significant concern all over the globe. Unresolved occupational stress leads to dissatisfaction in job, poor performance in work, psychological distress, lack of concentration and motivation [16], poor mental and physical health and wellbeing, absenteeism, turnover rate and a feeling of quitting the job [17]. It also leads to lack of commitment towards the organization [1].

The negative impact of stress can be minimized or even reduced if one is able to understand the causes of stress, its consequences and the appropriate coping strategies to manage stress [5].

An individual's affective development and health is influenced by his success or failure at work. Emotions are the primary determinants of behavior and achievement at work. They influence a person's well-being as well as the social climate at work, which in turn affects an individual's work related motivation levels and henceforth their performance outcomes [18]. Emotions if properly used are an essential tool for successful and fulfilling life as they alter our perception, memory and thought processes, increase adaptability, build trust, make us confident, and motivate us to achieve our goals and shape our future behaviour [7]. But if emotions are out of control, the result can be disastrous. Goleman stated that one third of the difference in predicting life success is due to technical skills and cognitive ability while two third is due to emotional competence.

According to a study done on 300 secondary school teachers it was found that by increasing the emotional intelligence of the teachers their occupational stress was reduced and their work performance improved [13]. Emotional intelligence has a strong moderating role in reducing stress and plays a very significant role in accomplishing personal and organizational objectives. The employees who use emotional intelligence are less stressed and are the best employees in the organizations [2].

An employee with high emotional intelligence is able to respond appropriately to workplace stress and to emotional behavior of his co-workers. According to Darvish \& Nasrollahi [4], emotional intelligence is a set of abilities and skills that increases the individual's ability against stress and it is a factor that seems to have a relationship with managers' and employees' occupational stress.

Cherniss and Adler [3] outlined four main reasons why the workplace is a logical setting for evaluating and improving emotional intelligence competencies:

1. Most adults spend the majority of their waking hours at work. 
2. Emotional intelligence competencies are critical for success in most jobs.

3. Many adults enter the workforce without the competencies necessary to succeed or excel at their job.

Earlier, workplace was dominated mostly by male employees, but now even women have formed an important part of workplace settings. The number of women employees are increasing considerably

The Economic Times on the $13^{\text {th }}$ of May, 2009 stated that according to a paper commissioned by NASSCOM's ongoing gender inclusivity initiative, India has more working women than any other country [8]. According to Rao a management consultant in Hyderabad, other than wanting to excel and showing their worth, generating income and maintaining a reasonable standard of living are the driving force which motivate women to take up employment [11].

Work has a lot of positive impact on women. It gives them sense of fulfillment as they feel they are contributing to the society, it gives them a sense of identity and increases their self-esteem. Work provides them with financial security and gives them a sense of safety.

In the Indian societal context, the traditional roles of women has been conducting household chores and raising children, and her identity is linked to the institutions of marriage, family and children [14]. Therefore, for working women it becomes increasingly difficult to handle the work and family together as the responsibility at work and the major activities at home lie on her shoulders. This balancing between work and family demands become an increasing cause of stress in their lives.

Since women have become an essential part of the Indian workforce and thus Indian economy, it becomes important to study job related stress in women. Today the job demands are increasing leading to more and more responsibilities. On one hand the jobs are paying well and have lot of positive impact on women, but on the other hand they also expect a lot of work and time in return. With the responsibility at home and increasing demands at work, women find it difficult to do justice to both, and this whole feeling of doing the best at both fronts and not being able to give their $100 \%$ to either makes them feel guilty. If this feeling persists for long they have no option than to decide between home and work. The situation becomes emotionally very draining, when one has to choose between work and family, and if they choose work it would not be expected in our society, so they have to choose the family. But this isn't the end of the trouble.

The answer to the problem is not leaving the job, as leaving the job makes them feel a loss of identity and self worth, but to be able to cope in an effective manner by, balancing roles, fixing priorities, time-management, being assertive, managing conflicts, being adaptive and so on.

It is important that women should be able to handle such situations. Thus, it is very essential for them to learn skills which will help them to deal with the situation. In a nutshell, enhancing EI skills would help in managing stress and accomplishing personal and professional goals.

The present study aimed at finding out the level of Occupational stress in working women and its relationship with their level of Emotional Intelligence. The research also aimed at finding out the coping strategies used by working women (with different levels of Emotional intelligence) to deal with stress.

\section{Method}

\subsection{Sample}

The sample comprised of 50 married women working in the corporate private firms, having an $8 \mathrm{hr}$ (9am to 5pm) job. They belonged to nuclear families with minimum qualification as Graduates. The eldest child was in the age of 6-13 years. Judgmental/ purposive or non-probability sampling was used to select the sample.

\subsection{Tools}

The tools used were, Self constructed Emotional Intelligence Scale for women (Cronbach's alpha $=.862$ ), and a self-constructed Occupational Stress Index, (Cronbach's alpha $=.918$ ). The coping strategies were studied through an self constructed interview schedule.

\subsection{Analyses}

The Data was analyzed using SPSS package. Correlations were computed to study the relationships between the two variables.

\section{Results}

The findings revealed that majority of the working women (46) perceived themselves as having above average level of EI (see Table 1). The mean score was found to be much above the theoretical midpoint. The mean scores of all the four domains of EI also fell in the high category, with majority of the participants perceiving themselves as having high level of self awareness (48), self management (39), social awareness (36) and relationship management (36). 
Table 1. Frequencies of participants at different Levels of Emotional Intelligence $(\mathrm{N}=50)$

\begin{tabular}{|l|l|l|}
\hline & $\mathrm{N}=50$ & $(\mathrm{f})$ \\
\hline Average & & 1 \\
\hline Above average & & 46 \\
\hline Well above average & & 3 \\
\hline
\end{tabular}

Further it was found that no one perceived themselves facing high level of occupational stress. Majority (31 out of 50) of women perceived as having average level stress, while some of the participants (19 out of 50) opined in the low category of occupational stress (see Table 2). The major stressors as perceived by them were timemanagement, work-family conflict and problems with senior colleagues.

Table 2. Frequencies of participants at different level of occupational stress $(\mathrm{N}=50)$

\begin{tabular}{|l|l|l|}
\hline & N=50 & (f) \\
\hline Low & & 19 \\
\hline Average & & 31 \\
\hline High & & -- \\
\hline
\end{tabular}

The Pearson's Product Moment Correlation Coefficient was used to measure the interrelationship. The test assumption of linearity was met while studying the correlations of certain variables and wherever it was not met the Nonparametric Spearman's rho was used there. The findings of the study revealed that a significant strong negative correlation existed between the total level of Emotional Intelligence and Occupational stress $\left(\mathrm{r}=-.733^{* *}, \mathrm{p}=.000\right)$. That is, when a working woman is high on emotional intelligence, she experiences lower levels of occupational stress (see Table 3).

Table 3. Relationship between the level of Emotional Intelligence and level of Occupational Stress in working women $(\mathrm{n}=50)$

\begin{tabular}{|l|l|l|l|}
\hline \multicolumn{2}{|l|}{} & & $\begin{array}{l}\text { Overall } \\
\text { occupational stress }\end{array}$ \\
\hline $\begin{array}{l}\text { Total Emotional } \\
\text { Intelligence }\end{array}$ & $\begin{array}{l}\text { Pearson } \\
\text { coefficient }\end{array}$ & correlation & $-.733^{* *}$ \\
\hline & Significance(2-tailed) & .000 \\
\hline \multicolumn{2}{|l|}{} & $\mathrm{N}$ & 50 \\
\hline
\end{tabular}

** Co-relation is significant at the 0.01 level (2tailed)

Further a significant high negative correlation was found between the overall level of occupational stress and the domain of self-management ( $\mathrm{p}=-$ $\left..646^{* *}, r=.000\right)$. The domain of social awareness had a significant negative correlation with the overall level of occupational stress but to a modest level $(\mathrm{p}=-.470 * *, \mathrm{p}=.000)$ [Refer Table no.4]

Table 4. Relationship between the Domains of Emotional Intelligence and the level of Occupational Stress

\begin{tabular}{|l|l|l|l|}
\hline & $\begin{array}{l}\text { Overall } \\
\text { occupationa } \\
1 \text { stress }\end{array}$ & $\begin{array}{l}\text { Pearson's } \\
\text { Correlation } \\
\text { coefficient }\end{array}$ & $\begin{array}{l}\text { Significance } \\
\text { (2-tailed) }\end{array}$ \\
\hline $\begin{array}{l}\text { Self- } \\
\text { awareness }\end{array}$ & & $-.518^{* *}$ & .000 \\
\hline $\begin{array}{l}\text { Self- } \\
\text { manageme } \\
\text { nt }\end{array}$ & $-.646^{* *}$ & .000 \\
\hline $\begin{array}{l}\text { Social } \\
\text { awareness }\end{array}$ & & $-470^{* *}$ & .000 \\
\hline $\begin{array}{l}\text { Relationsh } \\
\text { ip } \\
\text { manageme } \\
\text { nt }\end{array}$ & $-595^{* *}$ & .000 \\
\hline
\end{tabular}

All the sub-scales of occupational stress also had high significant negative correlations with the overall level of emotional intelligence, except for the sub-scales of under participation and powerlessness, work-family conflict and gender discrimination (see Table 5).

Table 5. Relationship between the level of emotional intelligence and the sub-scales of Occupational Stress Index

\begin{tabular}{|l|l|l|l|}
\hline $\begin{array}{l}\text { Sub-scale of } \\
\text { Occupational } \\
\text { Stress }\end{array}$ & $\begin{array}{l}\text { Emotional } \\
\text { Intelligence }\end{array}$ & $\begin{array}{l}\text { Significance } \\
\text { (2-tailed) }\end{array}$ \\
\hline $\begin{array}{l}\text { 1. Work } \\
\text { overload }\end{array}$ & $\begin{array}{l}\text { Pearson's } \\
\text { Correlation }\end{array}$ & $-.531^{* *}$ & .000 \\
\hline $\begin{array}{l}2 . \text { Role } \\
\text { ambiguity }\end{array}$ & $\begin{array}{l}\text { Pearson's } \\
\text { Correlation }\end{array}$ & $-.562^{* *}$ & .000 \\
\hline $\begin{array}{l}\text { 3. Role } \\
\text { conflict }\end{array}$ & $\begin{array}{l}\text { Pearson's } \\
\text { Correlation }\end{array}$ & $-.574^{* *}$ & .000 \\
\hline $\begin{array}{l}\text { 4. } \\
\text { Unreasonable } \\
\text { political/group } \\
\text { pressure }\end{array}$ & $\begin{array}{l}\text { Pearson's } \\
\text { Correlation }\end{array}$ & $-.614^{* *}$ & .000 \\
\hline $\begin{array}{l}\text { 5. Lack of } \\
\text { appreciation } \\
\text { and due merit }\end{array}$ & $\begin{array}{l}\text { Pearson's } \\
\text { correlation }\end{array}$ & $-.568^{* *}$ & .000 \\
\hline $\begin{array}{l}\text { 6. Under } \\
\text { participation } \\
\text { and } \\
\text { powerlessness }\end{array}$ & $\begin{array}{l}\text { Pearson's } \\
\text { Correlation }\end{array}$ & $-.462^{* *}$ & .001 \\
\hline $\begin{array}{l}7 . \text { Intrinsic } \\
\text { impoverishme } \\
\text { nt }\end{array}$ & $\begin{array}{l}\text { Pearson's } \\
\text { Correlation }\end{array}$ & $-.654^{* *}$ & .000 \\
\hline $\begin{array}{l}\text { 8. Strenuous } \\
\text { working } \\
\text { environment }\end{array}$ & $\begin{array}{l}\text { Pearson's } \\
\text { correlation }\end{array}$ & $-.507^{* *}$ & .000 \\
\hline $\begin{array}{l}\text { 9. Work- } \\
\text { family conflict }\end{array}$ & $\begin{array}{l}\text { Pearson's } \\
\text { correlation }\end{array}$ & $-.472^{* *}$ & .003 \\
\hline 10 Gender & Pearson's & -.343 & .015 \\
\hline
\end{tabular}


\begin{tabular}{|l|l} 
discrimination & correlation
\end{tabular}

** Co-relation is significant at the 0.01 level (2-tailed)

The results for coping strategies were categorized according to the level of EI the participant had. As most of the participant (46) perceived themselves as having above average level of EI, the coping strategies used by them have been stated here in this section.

The strategies that were used most often by women who perceived themselves as above average level of EI, were confronting the stress (23), taking support from friends and family members (22), seeking inner wisdom (20), talking and discussing with people from office (19) and taking spiritual help (19), while the strategies of compromising (40), relaxation/recreation (26), engaging in physical activity (21) and transfer of negative feelings (20) were used sometimes. The strategies that were found to be most effective were that of confronting the stress (35), taking spiritual help (28), seeking inner wisdom (26), talking and discussing with people from office (24), engaging in a creative expression (23) and relaxation/recreation (23). Strategies such as taking a break/changing the job (22) and transfer of negative feelings (22) were found to be not very effective strategies in coping with stress. Few of the working women with above average level of EI (7) stated categorically that they do not use the strategies like taking a break/ changing the job, or transfer of negative feelings as they do not lead to any kind of relief from stress.

Strategies like avoidance/ withdrawal, forcing/ competition, accommodation were used by respondents sometime at a temporary level if the situation demanded or in order to calm the situation, but were not used often as they were found to be not very effective or moderately effective in dealing with occupational stress.

The respondents were further asked regarding the three coping strategies that help them to deal with stress the best and it was found that Channelizing the stress, engaging in recreational activities (like reading, watching T.V., relaxation, outings with friends and family members) (22), taking spiritual help, going to one's place of worship (17), were the major strategies that were helping the working women (with above average level of EI) to deal with stress the best. Talking or discussing with friends and family members, discussing with colleagues, seeking inner wisdom and engaging in creative expression (14 each) were few other strategies that were helping them to deal with stress the best.

The respondents were also asked for the reasons of how are the three coping strategies helping them the best. The results showed that the strategy of channelizing the stress, engaging in recreational activities assisted them in relaxing themselves, being calm, reframing their stressful routine and also in diverting their mind and not thinking about the stressful situation (24). The method of taking spiritual help facilitated them in times of trouble and gave them inner strength and courage to fight with the situation. The other findings revealed that discussing the issue with their office mates helped them a lot as they felt lighter; it gave them an assurance that they are not the only one; also they were better able to generate solutions and know other people's perspective regarding a similar kind of a situation (17). Talking with friends also helped them in terms of feeling lighter and giving the respondents a sense of belongingness (15)

\section{Discussion}

Emotional Intelligence is a desirable trait and everyone should possess atleast average to high level of EI to be able to function properly. When a tool is made to measure emotional intelligence, an option where zero level of Emotional Intelligence exists is never present, because a human possibly cannot be without emotions and feelings. Therefore a person with very low or low levels of EI would or can be an indication of the person having a certain emotional disorder or problem in emotional regulation. While the kind of sample population that the research catered to was expected to be a normal population without any mental or emotional disorder or problem. The research thus, assumed that all respondents would possess atleast average or above average level of emotional intelligence. The findings of the current research supported the assumption. More had also supported the above assumption by stating that an average level of emotional intelligence is the minimum requirement for survival. However, to succeed and prosper in life, emotional intelligence should be higher.

A higher level of emotional intelligence is found to have many benefits for an individual. Emotional intelligence gives rise to emotional sensitivity and increases the potential for emotional learning and management skills, which can help us to maximise our long term happiness and survival. We are all emotional beings, more emotional than we seem to realize. Everyday we live with feelings and emotions [9]. An organization (6 seconds) working on Emotional intelligence compiled the benefits of high levels of EI in an article; the article indicated that high levels of EI have benefits for an individual, it is beneficial for her education, health, business and on his/ her life as a whole. People who are better able to perceive other people's emotions are better able to handle challenges and build stronger social networks [10].

The findings of the present study are thus, advantageous and the high levels of EI can have 
various implications in the life of working women both professionally and personally. For women it is very difficult to separate her professional life from her personal life, thus having a high level of EI would play a significant role in the life both at a personal and professional level. An article by Aralkatti on the official webpage of the India's Defence R\& D organization (Mahila Kalyan Manch part of the organization) supported the researchers viewpoint as she stated that women who have higher levels of EI are likely to be more assertive and they express their feelings directly, and they tend to feel positive about themselves; these women are outgoing and gregarious and express their feelings appropriately, they also can cope better with stress and are social, friendly and comfortable with themselves. They also display qualities like high self-esteem, mood management, and self motivation.

Discussing issues with the colleagues and talking out with friends were two stated reasons that helped the participants in coping and feeling happy and satisfied. One of the reason for this above average level of EI and average level of stress in the study participants may be because being in the city of Mumbai, there are long travelling hours, and women have friends who travel together and thus by talking out their problems with friends and colleagues they feel relieved and do not carry the burden of work to home and thus are able to carry out the household responsibilities effectively.

Another reason for lower stress could be the support of help from outside (home maids), who do the entire household chores and even cook the food. That also gives the working women lot of time to spend with her family. As the women in this study were working in private corporate sector, they were earning good salary and so could spend on hiring help.

Looking at the demographic profile most of the participant had one child and the rest had 2 children and between the age range of 8-12 years. Thus children being in the school going age were capable of taking care of themselves with the help available. Also the burden of studies may not be so much as they were in $3^{\text {rd }}$ to $6^{\text {th }}$ standard still away from the board exams.

Another finding of the present study, the significantly high negative correlations between the level of Occupational stress and Emotional intelligence has been supported and discussed by experts and researches in the field. Mayer, Caruso \& Salovey (1999), believed that the person who can regulate their emotional states are healthier because they accurately perceive and appraise their emotional states, know how and when to express their feelings, and can effectively regulate their mood states. On the other hand positive emotions may indeed undo the lingering effects of negative emotions that narrow one's thought-action range. Goleman stated in his findings that individuals with high level of emotional intelligence, pronounced by the ability to recognize and express emotions as well as to manage and control them, showed the ability to better cope with stress and suffer less from adverse health outcomes [7].

It was interesting to note that the 3 participants with well above average level of EI used coping methods of avoidance, forcing / competition only rarely or sometimes and did not find it very effective or find it only moderately effective. All the 3 respondents felt that the coping method of seeking inner wisdom and taking spiritual help are very effective in dealing with occupational stress. When analyzed further it was found that all three of them had high level of self-awareness and both these strategies were to do more with oneself, selftalk. Since the participants were high on selfawareness they would have found these methods very effective. The only participant with average level of EI said that the coping methods that were helping her best were that of discussing with colleagues, keeping career options open and helping her colleagues know her work, so that her work could be done even in her absence. The rationale given by her was that it helps her maintain her cool. It was interesting to know that how a person who does not have very high levels of EI chooses strategies which are not very positive and are to do with either shifting career, getting your work done from others. But the findings cannot be generalized because the sample with average level of EI was very small (only 1 ).

Zeidner, Matthews, \& Roberts in their book 'What we know about Emotional Intelligence' have said that people who have higher levels of EI might not avoid the stressful situations; they might also make coping mistakes less often and have an adaptive style of coping [18]. While the individuals with low EI might use the same maladaptive style of coping over and over again. A viable explanation that the author gave for this reasoning was that emotionally intelligent individuals have more constructive thought patterns.

The ability to effectively deal with emotions and emotional information in the workplace assists employees in managing occupational stress and maintaining psychological well-being [15]. He further concluded that stress reduction and health protection could be achieved not only by decreasing work demands (stressors), but also by increasing the personal resources of employees, including emotional intelligence. The increasing of EI skills (empathy, emotional self-control) necessary for successful job performance can help workers to deal more effectively with their feelings, and thus directly decrease the level of job stress and indirectly protect their health. 
Thus, the findings of the study has a clear implication for the organizations. As the participants in the study had above average EI and perceived average or low occupational stress, the findings further endorse the fact that EI helps in reducing stress by adapting positive methods of coping. Thus, its important for the Organizations to offer their employees a combination of EI and stress management training that would provide their employees additional necessary skills to deal effectively with the job requirements and handle the responsibilities at home front too. Stress reduction is not about decreasing the personal demands but it is about increasing the personal resources of employees by helping them to realize when they are stressed, to stay connected to their internal emotional experience, recognize and effectively use nonverbal cues and body language, enhance their ability to accurately read and respond to the nonverbal cues that other people send them at work and home, develop the capacity to meet challenges with humor, and resolve conflicts positively.

\section{References}

[1] Aghdasia S., Kiamaneshb A. R. and Ebrahim A. N. (2011). Emotional Intelligence and Organizational Commitment: Testing the Mediatory Role of Occupational Stress and Job Satisfaction, Procedia-Social and Behavioural Sciences, 29, 1965-1976

[2] Bano. B., \& Talib. P. (2012). Managing role stress through emotional intelligence- a model approach. International Journal of Human Resource Management and Research (IJHRMR) ISSN 22496874, Vol. 2 Issue, 63-72.

[3] Cherniss, C. \& Adler, M. (2000). Promoting emotional intelligence in organizations . Alexandria, VA: American Society for Training and Development.

[4] Darvish, H., \& Nasrollahi, A. A (2011). Studying the Relations between Emotional Intelligence and Occupational Stress: A Case Study at Payame Noor University. Petroleum-Gas University of Ploiesti BULLETIN. Vol. LXIII No. 2, 38 - 49. Economic Sciences Series

[5] Gibbons, R.M. \& B. Gibbons, (2007).

Occupational Stress in the chief Professional. Int. J. Contemporary Hospitality Management, 19, 32-42.

[6] Goleman, D., (1995). Emotional IntelligenceWhy it can matter more than IQ. New York: Bantam Books
[7] Goleman, D. (1998). Beyond Expertise. Working with Emotional Intelligence. New York: Bantam Books.

[8] http://economictimes.indiatimes.com/ articleshowpics/4524928.cms).

[9] http://azaz.essortment.com/emotionshumanermlj.htm retrieved on 20th November, 2009

[10] http://www.nexuseq.com/press/eq_benefits.pdf

[11] K, R. Rao. (2007) Management Consultant and Visiting Professor

[12] Mayer, J.D., Caruso, D., \& Salovey, P. (1999). Emotional intelligence meets traditional standards for an intelligence. Intelligence, 27, 267298.

[13] Mehta., A. (2013). A study of how emotional intelligence reduces occupational stress among teachers. Abhinav, International Monthly Refereed Journal of Research In Management \& Technology 20 www.abhinavjournal.com ISSN - 2320-0073 Volume II.

[14] Misra, G., \&Thakker, G. (1999). Job and wellbeing: The experiences of employed women. Psychological perspectives onstress and mental health. New Delhi: Concept publishing co.

[15] Oginska-Bulik, N. (2005). Emotional intelligence in the workplace: exploring its effects on occupational stress and health outcomes in human service workers. International Journal Occupational Medicine and Environmental Health. 18(2), 167-75.

[16] Salami S.O., Occupational Stress and Wellbeing: Emotional Intelligence, Self-efficacy, Coping, Negative Affectivity and Social Support as Moderators, The Journal of International Social Research, 3 (12), 387-398 (2010)

[17] Siu O. (2002). Occupational Stressors and Well-being among Chinese Employees: The Role of Organizational Commitment, Applied Psychology: An International Review, 51 (4), $527-$ 544.

[18] Zeidner, M.,Matthews, G.,\& Roberts, R. (2009). What we know about Emotional Intelligence: How It Affects Learning, Work, Relationships, and Our Mental Health. A Bradford Book, London: The MIT Press. 